\title{
Economic Analysis of Biomass Supply Chains: A Case Study of Four Competing Bioenergy Power Plants in Northwestern Ontario
}

\author{
Md. Bedarul Alam, Reino Pulkki, Chander Shahi, and Thakur Prasad Upadhyay \\ Faculty of Natural Resources Management, Lakehead University, 955 Oliver Road, Thunder Bay, ON, Canada P7B 5E1 \\ Correspondence should be addressed to Md. Bedarul Alam, mbalam@lakeheadu.ca
}

Received 9 April 2012; Accepted 11 July 2012

Academic Editors: A. Bosio and O. O. Fasina

Copyright (c) $2012 \mathrm{Md}$. Bedarul Alam et al. This is an open access article distributed under the Creative Commons Attribution License, which permits unrestricted use, distribution, and reproduction in any medium, provided the original work is properly cited.

Supply chain optimization for biomass-based power plants is an important research area due to greater emphasis on green energy sources. This paper develops and applies two optimization models to analyze the impacts of biomass competition on cost structures and gross margins for four competing biomass-based power plants in northwestern Ontario. Model scenarios are run to study the impacts of changes in parameters relevant to biomass type and processing technology, and prices of inputs and outputs on procurement costs. Cost minimization model shows that per unit procurement costs are directly proportional to the size of the power plants in all scenarios. Profit maximization model, on the other hand, shows that FMUs that are closer to the power plants make higher gross margins. However, the margins significantly increase for FMUs that are close to the power plants potentially offering higher prices. The variations in costs and gross margin structures under various model scenarios are explained by location of depletion cells relative to power plants, availability of each type of biomass in depletion cells, biomass demands, and differential processing costs for two types of biomass. These results can aid decision makers to make improved decisions related to biomass supply chains for bioenergy production.

\section{Introduction}

Forest biomass has been recognized as an alternative energy source since it is renewable and $\mathrm{CO}_{2}$ neutral [1]. However, renewable energy production from forest biomass faces many challenges due to uncertainty of its continuous supply [24]. The ever increasing demand of biomass for bioenergy production has enormously increased the transportation distances and costs for forest biomass procurement, which is spread over large geographical locations at varying distances from the power plant $[1,5]$. Further, the optimal harvest schedules become complicated if more power plants compete for available biomass feedstock over given space and time. This suggests a need for developing and using optimization models to analyze such problems for improved decision making in bioenergy production.

Canada's dependence on fossil fuel has changed in recent times, and forest biomass has become an important part of its energy picture, supplying about $4.7 \%$ of our primary energy demand, the second largest source of renewable energy after hydroelectricity [6]. A major application of bioenergy is found in the forest products industry of Canada. Beyond the forest industry, several independent power plants generate electricity from forest biomass in Canada. Currently, three major combined heat and power (CHP) plants in northwestern Ontario (NWO) are using forest biomass feedstock. These include Thunder Bay CHP plant (with annual feedstock demand of 730,000 green tonnes (gt)), Fort Frances CHP plant $(800,000 \mathrm{gt})$, and Dryden CHP plant $(480,000 \mathrm{gt})$. Atikokan power-generating station, another power plant in NWO, is currently being converted to use forest biomass feedstock instead of coal requiring 200,000 gt annually $[7,8]$. When all these plants become fully operational, the power plant managers (buyers of biomass) will need to have a sustainable and cost effective supply of biomass, and the contractors (suppliers of biomass) would 
like to increase their gross margins (profits) from biomass supply operations. Therefore, the optimization of forest biomass feedstock supply needs to be addressed both with cost optimization and profit maximization points of views.

Forest harvest residue (FHR), which includes tops and branches and unmerchantable wood left after stand harvesting, and underutilized wood (UW), which includes unharvested tree species that are not commercially important for timber, are the two most common forms of forest biomass used for bioenergy. Further, there are numerous options for comminuting forest biomass and several trucking and loading options having varying costs. Optimizing biomass procurement is, therefore, a complex problem with several supply and demand constraints.

A number of computational techniques from heuristics to advanced optimization models have been developed to model location specific biomass procurement problems [9-14]. These studies focus on bioenergy plant location problems for widespread forest biomass applications. The supply network normally consists of a single bioenergy production plant with many biomass supply regions [1517]. In this context, forest biomass transportation costs constitute the majority of forest fuel supply chain costs for energy production. Further studies in biomass procurement, therefore, focused on reducing overall transportation costs [18-21]. Linear programming (LP) models, which are a common technique in operations research, have been used to optimize transportation distances and costs for forest biomass procurement for energy production at regional levels [22, 23]. Forest biomass feedstock data have also been analyzed using geographic information systems (GISs) techniques $[24,25]$. LP models have also been developed using GIS-based forest biomass data both for estimating the feedstock availability and for reducing transportation distances and costs [26-29]. However, all these studies have been conducted either in Nordic or in central European countries.

We found no such optimization models dealing with biomass supply competition among various power plants in the Canadian context with large contiguous wood supply areas. The purpose of this study is, therefore, to develop and apply optimization models to analyze the impact of interpower plant competition for the available biomass feedstock on cost structures and gross margins of each power plant in NWO. Specifically, the two models (one based on cost minimization and another on profit maximization) are developed. The cost minimization model is applied from the power plant managers' (buyers) perspective, and the profit maximization model is applied from the biomass suppliers' perspective. Several sensitivity analyses are run to study the impact of changes in parameters relevant to forest biomass processing technology, biomass types, and prices of inputs and outputs.

\section{Methods}

The flow chart in Figure 1 presents the methodology for developing the LP models for supplying forest biomass feedstock to the four power-generating stations. The study area, $324 \mathrm{~km} \times 516 \mathrm{~km}\left(167,184 \mathrm{~km}^{2}\right)$, consists of 18 FMUs west of Lake Nipigon in NWO. GIS data are collected from Land Information Ontario, Sustainable Forest Licence (SFL) holders, and consultant companies in the formats of Shapefile and Geodatabase [30-33]. The original vector data is first converted to raster and finally to spatial database text files for the entire research area using ArcGIS software. Three main spatial layers (land use, forest depletion, and cost layers) are prepared on a raster grid size of $1 \mathrm{~km} \times$ $1 \mathrm{~km}\left(1 \mathrm{~km}^{2}\right)$, where each cell represents a feature [34, 35]. Different data input methods are followed for different types of features. The dominant data input method is used to create a raster layer of forest land use class [35], where a grid code entity is assigned to each feature (productive forest, water/lake, and other land use), which occupies more than $50 \%$ of the cell area (detailed methodology of data input methods is provided by Alam et al. [36]). The percent occurrence method is used to prepare the depletion layer, where a code number is assigned to the grid cell depending on its depletion percentage. Before developing the marginal transport cost layer for each power plant, a raster layer of the road network for the research area is also developed using the presence/absence method of data input [35]. A grid code is assigned depending on the presence of different types of roads in a cell. The raster layer of the road network is converted to ASCII (.txt) format. A network optimization model is used to prepare the minimum cost layer for transporting forest biomass through the road network to the four power plants. The location of each power plant is used as the sink node during the data input and optimization processes. The vehicle considered for transporting forest biomass feedstock is a tractor with a 53-foot semitrailer (with belly). In Ontario the allowable legal payload weight for this type of tractor-trailer is taken as 40.55 tonnes $(\mathrm{t})$. The chargeout rate for biomass truck with operator is assumed to be $85 \mathrm{\$} \cdot \mathrm{h}^{-1}$. A fixed time for loading, unloading, and delay of 2.5 hours per trip is assumed. In this cost layer, the cost of transporting forest biomass from each road cell $\left(1 \mathrm{~km}^{2}\right)$ of the research area to the four power plants is established. Minimum cost zones (tessellations) for transporting forest biomass from each of the 100,061 forest cells to each of the four power plants are established in order to create biomass catchment areas for each power plant.

Two optimization models are developed for analyzing optimal supply of forest biomass from depletion cells to the four power plants. The objective function in the first model is to minimize the total biomass feedstock procurement costs and in the second model is to maximize total profit (gross margin) of FMUs for supplying forest biomass feedstock from the forest cells to power plants. Even though these two models give the same solutions, the relative impacts of changing biomass prices are not captured by the cost minimization model. Changing biomass prices on part of bigger power plants will change the optimal solutions, which is best handled by the profit maximization model. The results of profit maximization are more relevant to the contractors (biomass suppliers) in order to evaluate the profitability of their operations in the given locations (FMUs). The parameters, indices, and variables used for 


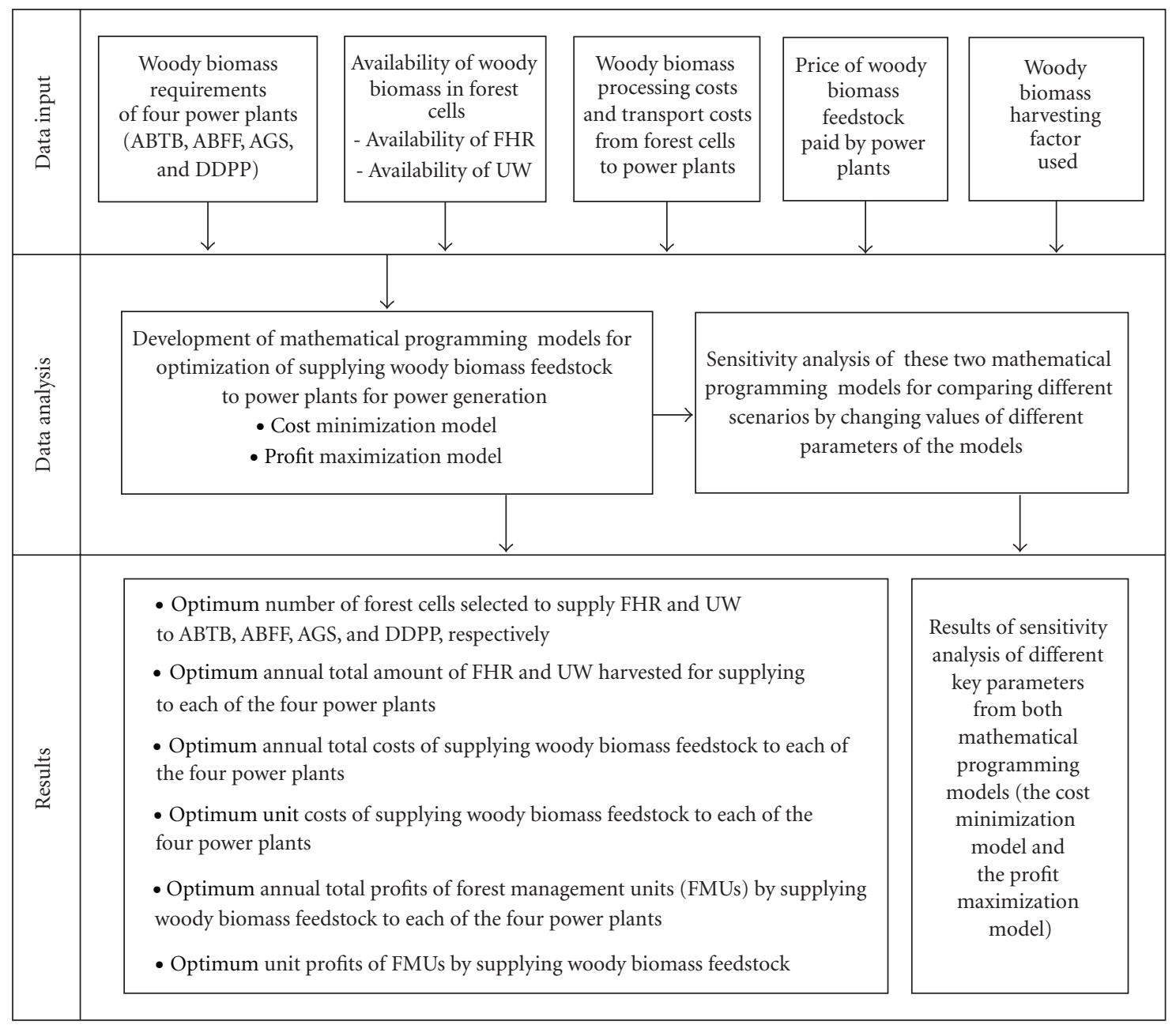

Figure 1: Flow chart of optimization models for supplying woody biomass feedstock to four major biomass based power plants in northwestern Ontario (NWO).

developing the two models using the General Algebraic Modeling System (GAMS) programming language are listed as follows.

\section{Indices:}

$i$ : power plants $(i$ : $1=$ Thunder Bay CHP plant, 2 $=$ Fort Frances CHP plant, 3 = Atikokan generating station and $4=$ Dryden CHP plant),

$j$ : forest cell in the depleted forest area $(j=1,2,3$, $\ldots, 19,315)$.

\section{Parameters:}

HF: harvesting factor,

PR: processing (harvesting and grinding/chipping) cost $\left(\$ \cdot \mathrm{gt}^{-1}\right)$ of FHR at roadside,

PU: processing (harvesting and grinding/chipping) cost $\left(\$ \cdot \mathrm{gt}^{-1}\right)$ of $\mathrm{UW}$ at roadside,

$\mathrm{DB}_{i}$ : annual forest biomass demand (gt) of each power plant,
$\mathrm{TR}_{j}$ : theoretical availability ( $\mathrm{gt}$ ) of FHR in a forest cell over 7 years (2002-2009),

$\mathrm{TU}_{j}$ : theoretical availability $(\mathrm{gt})$ of $\mathrm{UW}$ in a forest cell over 7 years (2002-2009),

$\mathrm{AR}_{j}$ : annual technical availability (gt) of FHR in a forest cell, calculated using (1)

$$
\mathrm{AR}_{j}=\frac{\mathrm{TR}_{j} \times \mathrm{HF}}{7}
$$

$\mathrm{AU}_{j}$ : annual technical availability (gt) of UW in a forest cell, calculated using (2)

$$
\mathrm{AU}_{j}=\frac{\mathrm{TU}_{j} \times \mathrm{HF}}{7}
$$

$\mathrm{TC}_{i j}$ : biomass transportation cost $\left(\$ \cdot \mathrm{gt}^{-1}\right)$ from the $j$ th forest cell to the $i$ th power plant including loading and unloading costs.

$P_{i}$ : price $\left(\$ \cdot \mathrm{gt}^{-1}\right)$ of forest biomass at the $i$ th power plant. 


\section{Variables:}

$R_{i j}$ : amount of annual FHR harvested (gt) from the $j$ th forest cell for the $i$ th power plant,

$U_{i j}$ : amount of annual UW harvested (gt) from the $j$ th forest cell for the $i$ th power plant,

$\mathrm{TB}_{i}$ : annual forest biomass (gt) brought in the $i$ th power plant,

TCB: total annual cost (\$) of biomass procurement, calculated using (3)

$$
\begin{aligned}
\mathrm{TCB}= & \sum_{i=1}^{4} \sum_{j=1}^{19315}\left(R_{i j}\left(\mathrm{PR}+\mathrm{TC}_{i j}\right)\right) \\
& +\sum_{i=1}^{4} \sum_{j=1}^{19315}\left(U_{i j}\left(\mathrm{PU}+\mathrm{TC}_{i j}\right)\right),
\end{aligned}
$$

TRB: total annual revenue (\$) from forest biomass supply to power plants, calculated using (4)

$$
\mathrm{TRB}=\sum_{i=1}^{4} \sum_{j=1}^{19315}\left(P_{i}\left(R_{i j}+U_{i j}\right)\right),
$$

TPB: total annual profit (\$) from forest biomass supply to power plants, calculated using (5)

$$
\begin{aligned}
\mathrm{TRB}= & \sum_{i=1}^{4} \sum_{j=1}^{19315}\left(P_{i}\left(R_{i j}+U_{i j}\right)\right) \\
& -\sum_{i=1}^{4} \sum_{j=1}^{19315}\left(R_{i j}\left(\mathrm{PR}+\mathrm{TC}_{i j}\right)\right) \\
& -\sum_{i=1}^{4} \sum_{j=1}^{19315}\left(U_{i j}\left(\mathrm{PU}+\mathrm{TC}_{i j}\right)\right) .
\end{aligned}
$$

The objective functions of two LP models, which minimize overall procurement costs and maximize total profit, are specified by (6) and (7), respectively. The constraints used in these models are specified by (8) to (12).

$$
\begin{aligned}
\text { Minimize TCB }= & \sum_{i=1}^{4} \sum_{j=1}^{19315}\left(R_{i j}\left(\mathrm{PR}+\mathrm{TC}_{i j}\right)\right) \\
& +\sum_{i=1}^{4} \sum_{j=1}^{19315}\left(U_{i j}\left(\mathrm{PU}+\mathrm{TC}_{i j}\right)\right) . \\
\text { Maximize TPB }= & \sum_{i=1}^{4} \sum_{j=1}^{19315}\left(P_{i}\left(R_{i j}+U_{i j}\right)\right) \\
& -\sum_{i=1}^{4} \sum_{j=1}^{19315}\left(R_{i j}\left(\mathrm{PR}+\mathrm{TC}_{i j}\right)\right) \\
& -\sum_{i=1}^{4} \sum_{j=1}^{19315}\left(U_{i j}\left(\mathrm{PU}+\mathrm{TC}_{i j}\right)\right),
\end{aligned}
$$


TABLE 1: Estimates of parameters used in BASE scenario of the model.

\begin{tabular}{lccc}
\hline Descriptions & Unit & Estimates & Remarks \\
\hline Harvesting and processing costs of FHR & $\$ \cdot \mathrm{gt}^{-1}$ & 26 & Forest BioProducts Inc. (2006) [7] \\
Harvesting and processing costs of UW & $\$ \cdot \mathrm{gt}^{-1}$ & 31 & Forest BioProducts Inc. (2006) [7] \\
Fixed cost due to load/unload overhead & $\$ \cdot \mathrm{gt}^{-1}$ & 5.24 & Own estimate \\
Charge rate of biomass truck & $\$ \cdot \mathrm{hr}^{-1}$ & 85 & Alam et al. (2012) [36] \\
Biomass demand of ABTB CHP plant & $\mathrm{gt} \cdot \mathrm{yr}^{-1}$ & 730,000 & Power plant data \\
Biomass demand of ABFF CHP plant & $\mathrm{gt} \cdot \mathrm{yr}^{-1}$ & 800,000 & Power plant data \\
Biomass demand of AGS Power plant & $\mathrm{gt} \cdot \mathrm{yr}^{-1}$ & 200,000 & Power plant data \\
Biomass demand of DDPP CHP plant & $\mathrm{gt} \cdot \mathrm{yr}^{-1}$ & 480,000 & Power plant data \\
Range of availability of FHR & $\mathrm{gt} / \mathrm{km}^{2}$ & $525.6-5,256$ & Alam et al. (2012) [36] \\
Range of availability of UW & $\mathrm{gt} / \mathrm{km}^{2}$ & $0-4,730.4$ & Alam et al. (2012) [36] \\
Harvesting factor of FHR & $\% \mathrm{of} \mathrm{FHR}^{2}$ & 61 & Own estimate \\
Harvesting factor of UW & $\% \mathrm{of} \mathrm{UW}$ & 61 & Own estimate \\
Price of biomass at power plants & $\$ \cdot \mathrm{gt}^{-1}$ & 39 & Own estimate \\
Number of depleted forest cells & $\mathrm{No}$ & 19,315 & Alam et al. (2012) [36] \\
\hline
\end{tabular}

FHR: forest harvest residue, UW: underutilized wood, gt: green tonne, hr: hour, yr: year, ABTB: Abitibi-Bowater Thunder Bay Power Plant, CHP: combined heat and power, ABFF: Abitibi-Bowater Fort Frances Power Plant, AGS: Atikokan generating station, DDPP: Domtar Dryden Power Plant.

there are many forest cells closer to this power plant along with a denser network of higher class and straighter roads. There is no competition for the Dryden CHP plant for forest biomass supply from any other power plant in the research area on the northern side. Similarly, Thunder Bay CHP plant is located in the southeastern part of research area. There is no competing power plant on its northern, eastern, and southern sides in the research area. The other two power plants, Atikokan and Fort Frances, which are located close to each other in the research area, might compete for the same forest biomass from some depletion cells depending upon their requirements. The cost zone map in Figure 2 shows the relative cost competitive areas for each power plant based on minimum transportation cost for each power plant from each forest cell. As more attributes (biomass density and economic) are introduced in the forest cells, the dynamics of competition among the four power plants would change.

3.2. Cost Analysis. The results of the cost minimization model provide an optimal solution for supplying forest biomass feedstock from forest cells to the four power plants on an annual basis by minimizing the total annual procurement (harvesting, processing, and transportation) costs of biomass, subject to the availability of forest biomass in each depleted forest cell and demand of each power plant. The model selects 11,790 and 2,991 cells in total for supplying FHR and UW, respectively, for all four plants. The more FHR cells are selected because the processing cost for FHR is less as compared to UW forest biomass. Figure 3 represents the distribution of optimal depletion forest cells that supply FHR and UW biomass to each power plant in the BASE scenario. Similar distributions of optimal depletion cells for different model scenarios can be produced; these are not reproduced here because of space limitations.

First, we discuss the results relating to the impacts of changing economic parameters (transportation and processing costs and prices) on cost structures. Results of the impacts of changing technological parameters (harvesting factors and biomass demand and availability) are discussed next. The number of cells selected for supplying FHR and UW forest biomass for each power plant, in each model scenario, is presented in Table 4. While observing number of selected cells in Table 4, we find more depletion cells for FHR in all scenarios for all plants, but lesser amount of biomass from FHR type is being harvested (Table 5) in most of the scenarios. This variation is explained by the fact that, on an average, the availability of FHR is about one-fourth of UW biomass type. The source of the information is the input dataset of the model.

Table 5 describes the distribution of biomass (both FHR and UW) amount being harvested from the optimal depletion cells for each plant under different model scenarios. The variations in number of depletion cells (Table 4) and biomass amount (Table 5) being selected by power plants are explained by amount of biomass requirement for each plant, availability of FHR and UW in each cell, relative processing costs of each biomass type, and the competition among the power plant for the biomass in the given cell. Further, these variations in distribution of optimal depletion cells and amount of biomass for both types explain the per unit biomass procurement cost structures for each power plant under different model scenarios (Table 6).

The 13 cost minimization model scenarios analyze the impacts of changing relevant economic (three scenarios) and technological (10 scenarios) parameters (as described in Table 2) on biomass procurement costs structures of the four power plants as shown in Table 6. The results of these scenarios are compared with that of the BASE scenario. The results in Table 6 show that per unit costs for Fort Frances, Thunder Bay and Dryden CHP plants, and Atikokan power plant are in descending order for all model scenarios, which indicate that the higher the biomass demand, the higher the per unit procurement cost. The reason for this is that power plants with more biomass 
TABLE 2: Definition and description of scenarios of cost minimization model.

\begin{tabular}{|c|c|}
\hline Scenario & Definition/description \\
\hline BASE & $\begin{array}{l}\text { The business-as-usual scenario captures the present reality of study area. The parameters used in this scenario are as } \\
\text { described in Table 1. This scenario helps compare the model results for the rest of the scenarios. }\end{array}$ \\
\hline \multicolumn{2}{|r|}{ Economic scenarios } \\
\hline INTC & $\begin{array}{l}\text { BASE, but } 20 \% \text { increase in biomass truck charge rate. This scenario tests the impact of change in transportation costs on the } \\
\text { biomass procurement cost structures which might be the case in future as truck charge rate has recently been increased in } \\
\text { NWO. }\end{array}$ \\
\hline INPC & $\begin{array}{l}\text { BASE, but } 10 \% \text { increase in harvesting and processing costs of FHR and UW. This tests the impacts of increased harvesting } \\
\text { and processing costs, likely to occur due to changes in economic factors, on procurement cost structures. }\end{array}$ \\
\hline DEPC & $\begin{array}{l}\text { BASE, but } 10 \% \text { decrease in harvesting and processing costs of FHR and UW. This scenario reflects potential improvements in } \\
\text { technology in future, thereby reducing the processing costs. }\end{array}$ \\
\hline \multicolumn{2}{|r|}{ Technological scenarios } \\
\hline INBA & BASE, but $10 \%$ increase in availability of both FHR and UW. \\
\hline \multirow[t]{2}{*}{ DEBA } & BASE, but $10 \%$ decrease in availability of both FHR and UW. \\
\hline & $\begin{array}{l}\text { These scenarios test the sensitivity of loosening and tightening of biomass availability constraints. This will help us } \\
\text { understand the changes in costs structures over the error margins }( \pm 10 \%) \text { of present estimates of biomass availability for } \\
\text { both types as the present estimates of these variables are based on samples of selected areas in FMUs of NWO, which might } \\
\text { have the range of errors tested by these scenarios as the present estimates of biomass availability are based on selected sample } \\
\text { forest cells. We feel that these estimates need to be improved in future work. }\end{array}$ \\
\hline IHR W1 & BASE, but 10\% increase in harvesting factors of both FHR and UW. \\
\hline IHR W2 & BASE, but $20 \%$ increase in harvesting factors of both FHR and UW. \\
\hline \multirow[t]{2}{*}{ IHFR } & BASE, 20\% increase in harvesting factor of FHR and no change in harvesting factor of UW. \\
\hline & $\begin{array}{l}\text { This set of scenarios tests the impacts of loosening the biomass availability constraints due to improved biomass harvesting } \\
\text { technology, likely to happen in future. }\end{array}$ \\
\hline DHR W & BASE, but $10 \%$ decrease in harvesting factors of both FHR and UW. \\
\hline \multirow[t]{2}{*}{ DHFR } & BASE, but $20 \%$ decrease in harvesting factor of FHR and no change in harvesting factor of UW. \\
\hline & $\begin{array}{l}\text { This set of scenarios tests the impacts of tightening the biomass availability, which might occur due to ecological and } \\
\text { environmental concerns in future. }\end{array}$ \\
\hline IHOR & $\begin{array}{l}\text { BASE, but 20\% increase in harvesting factor of FHR, and only FHR is extracted. This scenario explores the situation of } \\
\text { increased procurement costs due to present common practice of harvesting only FHR for bioenergy production instead of } \\
\text { harvesting both FHR and UW. }\end{array}$ \\
\hline INDP & $\begin{array}{l}\text { BASE, but } 10 \% \text { increase in woody biomass feedstock demand. This explores the impacts of higher biomass demand, likely to } \\
\text { happen due to expansion of power plants in future, on cost structures of biomass procurement. }\end{array}$ \\
\hline DEDP & $\begin{array}{l}\text { BASE, but } 10 \% \text { decrease in woody biomass feedstock demand of each of the four power plants. This scenario helps } \\
\text { understand the costs structures due to loosening of constraints on the biomass feedstock demand of power plants, which } \\
\text { might be the case in future. Selection of higher quality biomass and plants not operating in full capacity leads to lesser } \\
\text { biomass demands. }\end{array}$ \\
\hline
\end{tabular}

demand have to collect biomass from much longer distances. The range of unit procurement cost $\left(\$ \cdot \mathrm{ODt}^{-1}\right)$ for Fort Frances, Thunder Bay and Dryden CHP plants, and Atikokan power plant is $60.81-76.81,59.72-75.37,56.57-71.31$, and 56.03-70.39, respectively. This result shows that the highest per unit procurement cost (for all power plants on average a $16.77 \%$ increase from the BASE scenario) occurs with a $20 \%$ increase in transportation cost (INTC scenario). The lowest per unit procurement costs occurs with a $10 \%$ decrease in processing cost scenario (DEPC scenario). A decrease in processing cost by $10 \%$ resulted in a $7.44 \%$ decrease in per unit procurement costs for all power plants on average. Since transportation and processing costs form a major component of biomass supply chain, changes in these parameters have major impacts on per unit procurement cost for all power plants. These sensitivity results imply that policy should focus first on controlling transportation costs and then processing costs. The processing cost includes both productive machine time and idle time costs. The productive machine time can be improved by investing in improving the processing technology, and the idle time can be reduced by better scheduling of operations. Improving road network and vehicle configuration for hauling biomass can reduce the transportation costs. Consequently, one can achieve reduced procurements costs in biomass value chains with these improved measures.

After analyzing the sensitivities of changing economic parameters to the model solutions, we investigate further the impacts of changing relevant technological parameters in order to evaluate the resulting cost structures due to potential changing conditions of these parameters in future. In model scenarios INBA, IHRW1, IHRW2, IHFR, and DEDP, the per unit procurement costs decreased from the BASE scenario for all power plants with the highest decrease at the Atikokan 
TABLE 3: Definition and description of scenarios of profit maximization model.

\begin{tabular}{ll}
\hline Scenario & Description \\
BASE & $\begin{array}{l}\text { This is the business-as-usual scenario of the model which reflects the current field situation. The parameters for this scenario } \\
\text { are described in Table } 1 \text {. The results of other model scenarios are compared with that of this scenario. } \\
\text { BASE, but } 20 \% \text { increase in biomass truck charge rate. }\end{array}$ \\
INTC & $\begin{array}{l}\text { This scenario tests the impact of change in transportation costs, which is likely situation in future on gross margin structures } \\
\text { for each biomass supplying FMU, as truck charge rate has recently been increased in NWO. }\end{array}$ \\
IRTB1 & BASE, but $10 \%$ increase in price of biomass feedstock by Thunder Bay plant. \\
IRTB2 & BASE, but $20 \%$ increase in price of biomass feedstock by Thunder Bay plant. \\
IRFF1 & BASE, but $10 \%$ increase in price of biomass feedstock by Fort Frances plant. \\
IRFF2 & BASE, but 20\% increase in price of biomass feedstock by Fort Frances plant. \\
IRTF1 & BASE, but $10 \%$ increase in price of biomass feedstock by both Thunder Bay and Fort Frances plants. \\
IRTF2 & $\begin{array}{l}\text { BASE, but } 20 \% \text { increase in price of biomass feedstock by both Thunder Bay and Fort Frances plants. } \\
\text { This set of price increasing scenarios tests the sensitivity of different levels of prices of biomass feedstock to gross margin } \\
\text { structures of biomass supplying FMUs. These changes in prices are likely to be offered on the part of bigger power plants as } \\
\text { they require huge amounts of biomass to operate their power plants smoothly. Price increases are, therefore, assigned to two } \\
\text { bigger power plants, Thunder Bay and Fort Frances, in these scenarios. }\end{array}$ \\
&
\end{tabular}
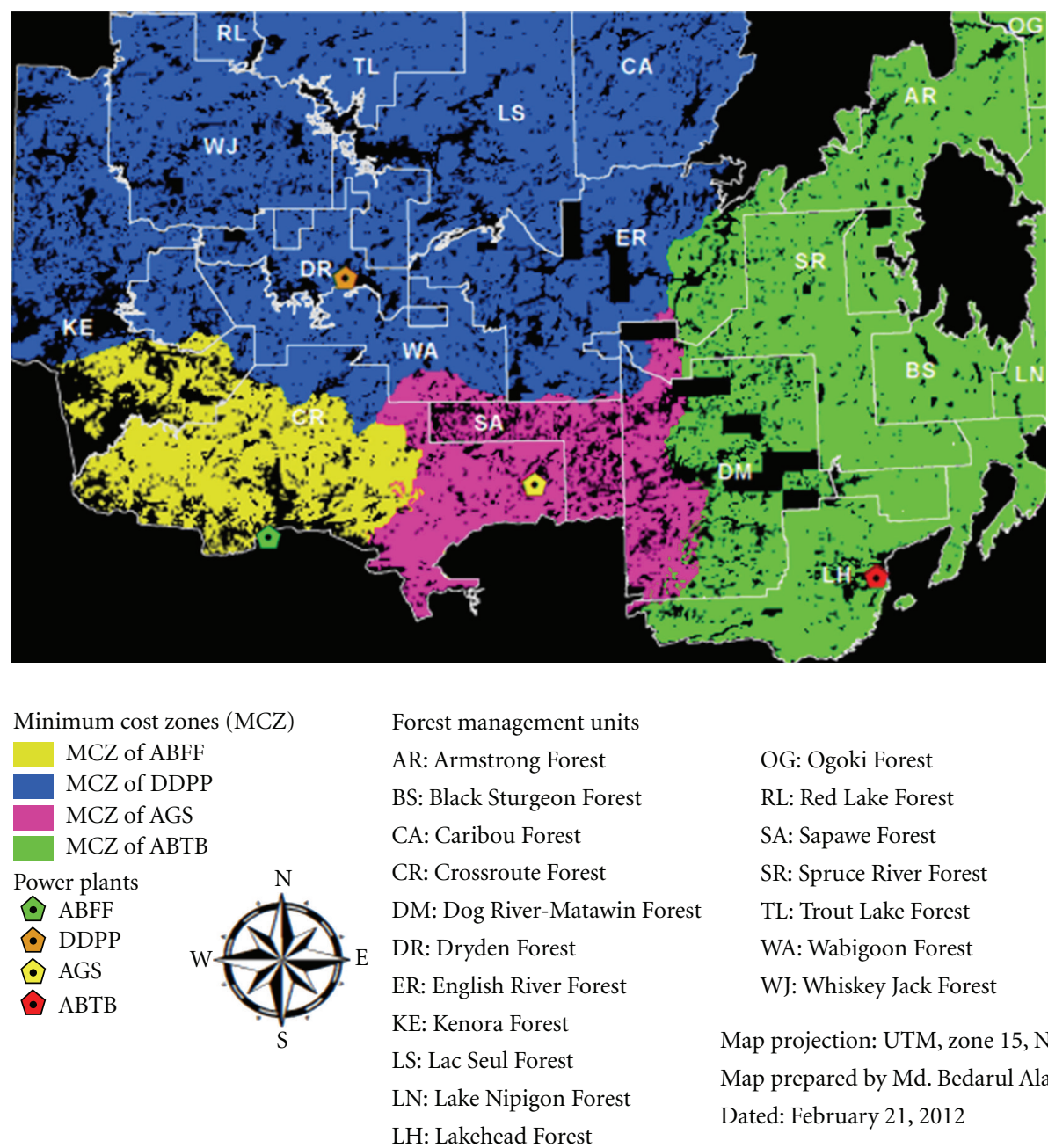

\begin{abstract}
OG: Ogoki Forest
RL: Red Lake Forest

SA: Sapawe Forest

SR: Spruce River Forest

TL: Trout Lake Forest

WA: Wabigoon Forest

WJ: Whiskey Jack Forest
\end{abstract}

Map projection: UTM, zone 15, NAD83

Map prepared by Md. Bedarul Alam

Dated: February 21, 2012

ABFF: Abitibi-Bowater Fort Frances Power Plant, DDPP: Domtar Dryden Power Plant, AGS: Atikokan

Generating Station, ABTB: Abitibi-Bowater Thunder Bay Power Plant

Figure 2: Minimum cost zones for four power plants in NWO. 


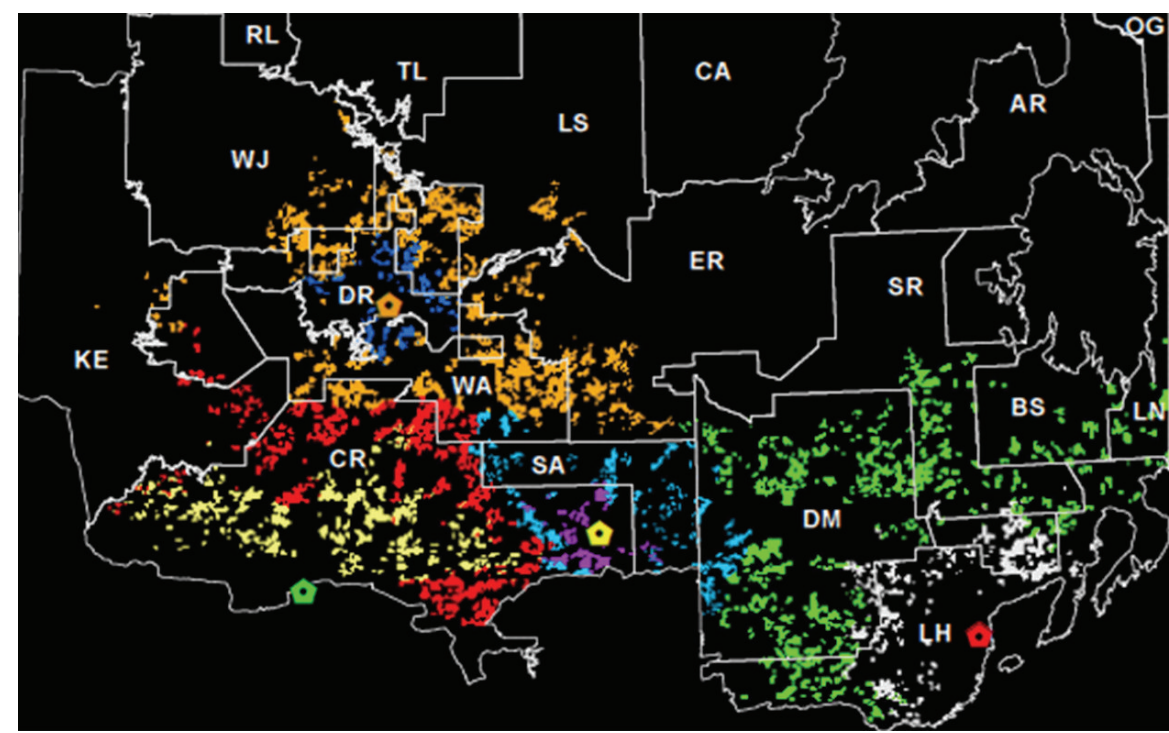

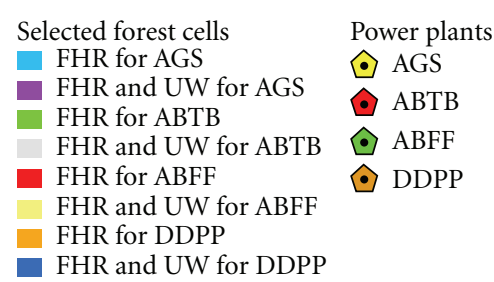

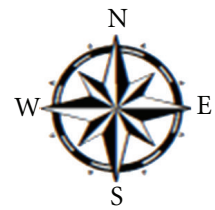

Forest management units

$\begin{array}{ll}\text { AR: Armstrong Forest } & \text { OG: Ogoki Forest } \\ \text { BS: Black Sturgeon Forest } & \text { RL: Red Lake Forest } \\ \text { CA: Caribou Forest } & \text { SA: Sapawe Forest } \\ \text { CR: Crossroute Forest } & \text { SR: Spruce River Forest } \\ \text { DM: Dog River-Matawin Forest } & \text { TL: Trout Lake Forest } \\ \text { DR: Dryden Forest } & \text { WA: Wabigoon Forest } \\ \text { ER: English River Forest } & \text { WJ: Whiskey Jack Forest }\end{array}$

KE: Kenora Forest

LS: Lac Seul Forest

LN: Lake Nipigon Forest

LH: Lakehead Forest
Map projection: UTM, zone 15, NAD83

Map prepared by Md. Bedarul Alam

Dated: February 21, 2012

FHR: Forest Harvest Residue, UW: underutilized wood, AGS: Atikokan Generating Station, ABTB: Abitibi-Bowater Thunder Bay Power Plant, ABFF: Abitibi-Bowater Fort Frances Power Plant, DDPP: Domtar Dryden Power Plant

FIGURE 3: Selected forest cells to harvest forest harvest residues (FHRs) and underutilized wood (UW) for four power plants (BASE scenario).

TABLE 4: The number of forest cells selected in different scenarios for supplying woody biomass to four power plants.

\begin{tabular}{lccccccccccc}
\hline \multirow{2}{*}{ Scenario } & \multicolumn{2}{c}{ Cells for ABFF (no.) } & \multicolumn{2}{c}{ Cells for ABTB (no.) } & \multicolumn{2}{c}{ Cells for DDPP (no.) } & \multicolumn{3}{c}{ Cells for AGS (no.) } & \multicolumn{3}{c}{ Total cells for 4 plants (no.) } \\
& FHR & UW & FHR & UW & FHR & UW & FHR & UW & FHR & UW & Total \\
\hline BASE & 3204 & 1320 & 3972 & 1004 & 3507 & 404 & 1107 & 263 & 11790 & 2991 \\
INTC & 3127 & 1338 & 3612 & 1093 & 3213 & 473 & 1034 & 283 & 10986 & 3187 & 14173 \\
INPC & 3239 & 1312 & 4152 & 950 & 3695 & 355 & 1142 & 249 & 12228 & 2866 & 15094 \\
DEPC & 3178 & 1327 & 3775 & 1056 & 3349 & 442 & 1055 & 276 & 11357 & 3101 & 14458 \\
INBA & 3138 & 1139 & 3816 & 860 & 3388 & 316 & 1135 & 197 & 11477 & 2512 & 13989 \\
IHR W1 & 3138 & 1139 & 3816 & 860 & 3388 & 316 & 1135 & 197 & 11477 & 2512 & 13989 \\
IHR W2 & 3090 & 981 & 3680 & 748 & 3285 & 242 & 1143 & 151 & 11198 & 2122 \\
IHFR & 3164 & 1155 & 3815 & 853 & 3334 & 279 & 1120 & 193 & 11433 & 2480 & 13320 \\
DEDP & 3133 & 1120 & 3808 & 844 & 3373 & 307 & 1138 & 190 & 11452 & 2461 & 13913 \\
DEBA & 3257 & 1555 & 4157 & 1162 & 3655 & 513 & 1097 & 328 & 12166 & 3558 & 15724 \\
DHR W & 3257 & 1555 & 4157 & 1162 & 3655 & 513 & 1097 & 328 & 12166 & 3558 & 15724 \\
DHFR & 3219 & 1501 & 4142 & 1152 & 3729 & 536 & 1086 & 325 & 12176 & 3514 & 15690 \\
IHOR & 6726 & - & 6197 & - & 3728 & - & 1849 & - & 18500 & - \\
INDP & 3254 & 1531 & 4132 & 1148 & 3642 & 502 & 1098 & 320 & 12126 & 3501 & 18500 \\
\hline
\end{tabular}

ABFF: Abitibi-Bowater Fort Frances Power Plant, ABTB: Abitibi-Bowater Thunder Bay Power Plant, DDPP: Domtar Dryden Power Plant, AGS: Atikokan Generating Station, FHR: forest harvest residue, UW: underutilized wood. 
TABLE 5: Annual amount of forest harvest residue and underutilized woody biomass supply to four power plants.

\begin{tabular}{|c|c|c|c|c|c|c|c|c|}
\hline \multirow{2}{*}{ Scenario } & \multicolumn{2}{|c|}{ Biomass for ABFF $\left(\mathrm{ODt} \cdot \mathrm{yr}^{-1}\right)$} & \multicolumn{2}{|c|}{ Biomass for ABTB $\left(\mathrm{ODt} \cdot \mathrm{yr}^{-1}\right)$} & \multicolumn{2}{|c|}{ Biomass for DDPP $\left(\mathrm{ODt} \cdot \mathrm{yr}^{-1}\right)$} & \multicolumn{2}{|c|}{ Biomass for AGS (ODt $\left.\cdot \mathrm{yr}^{-1}\right)$} \\
\hline & FHR & UW & FHR & UW & FHR & UW & FHR & UW \\
\hline BASE & 194,513 & 285,487 & 215,014 & 222,986 & 197,421 & 90,579 & 62,465 & 57,535 \\
\hline INTC & 190,401 & 289,599 & 194,953 & 243,047 & 182,339 & 105,661 & 57,920 & 62,081 \\
\hline INPC & 196,228 & 283,772 & 227,051 & 210,949 & 208,057 & 79,943 & 64,900 & 55,100 \\
\hline DEPC & 192,864 & 287,136 & 203,419 & 234,581 & 189,287 & 98,713 & 59,541 & 60,459 \\
\hline INBA & 209,309 & 270,691 & 227,206 & 210,795 & 209,525 & 78,475 & 71,251 & 48,749 \\
\hline IHR W1 & 209,309 & 270,691 & 227,206 & 210,795 & 209,525 & 78,475 & 71,251 & 48,749 \\
\hline IHR W2 & 225,238 & 254,762 & 237,835 & 200,165 & 222,566 & 65,434 & 78,718 & 41,282 \\
\hline IHFR & 230,481 & 249,519 & 247,802 & 190,199 & 225,040 & 62,960 & 76,442 & 43,558 \\
\hline DEDP & 189,924 & 242,077 & 206,110 & 188,090 & 189,754 & 69,446 & 65,021 & 42,979 \\
\hline DEBA & 177,857 & 302,144 & 204,864 & 233,136 & 185,375 & 102,625 & 55,427 & 64,573 \\
\hline DHR W & 177,857 & 302,144 & 204,864 & 233,136 & 185,375 & 102,625 & 55,427 & 64,573 \\
\hline DHFR & 156,204 & 323,796 & 181,324 & 256,676 & 168,648 & 119,352 & 48,631 & 71,369 \\
\hline IHOR & 480,000 & - & 438,000 & - & 288,000 & - & 120,000 & - \\
\hline INDP & 197,481 & 330,519 & 226,116 & 255,684 & 204,956 & 111,844 & 61,695 & 70,305 \\
\hline
\end{tabular}

ABFF: Abitibi-Bowater Fort Frances Power Plant, ABTB: Abitibi-Bowater Thunder Bay Power Plant, DDPP: Domtar Dryden Power Plant, AGS: Atikokan Generating Station, FHR: forest harvest residue, UW: underutilized wood.

power plant (Table 6). On the other hand, under the model scenarios DEBA, DHRW, DHFR, IHOR, and INDP the per unit procurement costs increased from the BASE scenario for all power plants with the highest increase at the Atikokan power plant. The explanation for these higher changes in per unit procurement costs for the Atikokan power plant is that it has the lowest biomass demand compared to other power plants; it is located near the favorable depletion cells and biomass availability (Figures 2 and 3). However, in IHOR (only FHR biomass with $20 \%$ more harvesting factor) scenario, the increase in per unit cost for Atikokan power plant is the least compared to others. Although more FHR biomass is available in the IHOR scenario, there is higher competition for this type of biomass because UW is not being collected, and hence there is an increase in per unit cost compared to the BASE scenario for all power plants. In this scenario, the Atikokan power plant has least increment in per unit cost due to its lower demand for biomass relative to the other power plants. After the Atikokan plant, Fort Frances, the biggest power plant, shows higher increases and decreases in per unit procurement costs for most of the scenarios (Table 6), albeit with small variations among the plants by scenarios. The more interesting results are found in the IHOR scenario, where Dryden CHP plant has the highest increase $(9.97 \%)$ in per unit cost compared to the BASE scenario. Further, the aggregate impacts of the economics and technological model scenarios are reflected in Figure 4, where we present the power plantwise total biomass procurement costs by scenarios. The bars in Figure 4 contrast with the results of per unit costs by scenarios. For example, the highest total costs for each power plant are shown in the INDP scenario, whereas the highest per unit cost is found in the INTC scenario.

Increasing harvesting factors causes more declines in per unit procurement costs suggesting that the present harvesting factor level needs to be increased for reduced per unit procurement cost. This is possible given that the depletion cells being used in this study are only from productive forest area, and it excludes the ecologically sensitive areas in NWO. Further, IHOR scenario showing us the highest per unit procurement cost, which suggests current emphasis on collecting only FHR for bioenergy purpose, would lead to higher per unit procurement cost. This, therefore, suggests for harvesting standing underutilized tree species to reduce per unit procurement cost.

3.3. Profit Analysis. The results of the profit maximization model provide an optimal solution for supplying forest biomass feedstock from forest cells to the four power plants on an annual basis by maximizing the total gross margin, subject to the availability of forest biomass in each depleted forest cell and meeting the biomass demand of each power plant. These results of gross margin structures are relevant from the biomass supplier's (contractors) perspective as these are based on biomass supplying FMUs (Table 7), where the contractors operate their business. The results of per unit profit $\left(\$ \cdot \mathrm{ODt}^{-1}\right)$ for each FMU that supplies biomass to the four power plants in the BASE and seven other scenarios are shown in Table 7. The profit for any FMU depends on the price of biomass being offered by the power plants. In the BASE scenario, most of the FMUs make positive profit.

Although 19,315 depletion cells used in this study are from 18 FMUs, the optimal depletion cells selected by the model fall only in 13 FMUs for all the scenarios. In the BASE scenario, only the Kenora and Lake Nipigon FMUs show negative gross margins (Table 7) as the optimal depletion cells falling in these FMUs are relatively farther away from the power plants (Figure 2). While testing the sensitivity of increasing truck charge rate by $20 \%$ (INTC scenario), only four FMUs (Dog River-Matawin, Dryden, English River, and Lac Seul FMUs) make positive profit. These results suggest that, in future, contractors operating in most of the FMUs 
TABLE 6: Per unit procurement cost of woody biomass supply to four power plants.

\begin{tabular}{|c|c|c|c|c|}
\hline \multirow{2}{*}{ Scenario } & \multicolumn{4}{|c|}{ Unit procurement cost of biomass supply $\left(\$ \cdot \mathrm{ODt}^{-1}\right)$} \\
\hline & $\mathrm{ABFF}$ & ABTB & DDPP & AGS \\
\hline BASE & 65.64 & 64.49 & 61.20 & 60.76 \\
\hline INTC & $76.81(17.03 \%)$ & $75.37(16.87 \%)$ & $71.31(16.52 \%)$ & $70.39(15.85 \%)$ \\
\hline INPC & $70.45(7.34 \%)$ & $69.24(7.37 \%)$ & $65.79(7.51 \%)$ & $65.47(7.75 \%)$ \\
\hline DEPC & $60.81(-7.34 \%)$ & $59.72(-7.40 \%)$ & $56.57(-7.56 \%)$ & $56.03(-7.79 \%)$ \\
\hline INBA & $65.26(-0.58 \%)$ & $64.17(-0.49 \%)$ & $60.86(-0.54 \%)$ & $60.21(-0.90 \%)$ \\
\hline IHR W1 & $65.26(-0.58 \%)$ & $64.17(-0.49 \%)$ & $60.86(-0.54 \%)$ & $60.21(-0.90 \%)$ \\
\hline IHR W2 & $64.89(-1.13 \%)$ & $63.89(-0.93 \%)$ & $60.57(-1.03 \%)$ & $59.86(-1.48 \%)$ \\
\hline IHFR & $65.08(-0.85 \%)$ & $64.01(-0.74 \%)$ & $60.61(-0.95 \%)$ & $60.02(-1.22 \%)$ \\
\hline DEDP & $65.21(-0.64 \%)$ & $64.14(-0.54 \%)$ & $60.83(-0.60 \%)$ & $60.17(-0.97 \%)$ \\
\hline DEBA & $66.11(0.72 \%)$ & $64.86(0.57 \%)$ & $61.58(0.63 \%)$ & $61.23(0.77 \%)$ \\
\hline DHR W & $66.11(0.72 \%)$ & $64.86(0.57 \%)$ & $61.58(0.63 \%)$ & $61.23(0.77 \%)$ \\
\hline DHFR & $66.26(0.96 \%)$ & $65.02(0.82 \%)$ & $61.85(1.07 \%)$ & $61.46(1.16 \%)$ \\
\hline IHOR & $70.41(7.27 \%)$ & $68.07(5.56 \%)$ & $67.30(9.97 \%)$ & $63.14(3.93 \%)$ \\
\hline INDP & $66.06(0.65 \%)$ & $64.82(0.52 \%)$ & $61.55(0.58 \%)$ & $61.18(0.70 \%)$ \\
\hline
\end{tabular}

ABFF: Abitibi-Bowater Fort Frances Power Plant, ABTB: Abitibi-Bowater Thunder Bay Power Plant, DDPP: Domtar Dryden Power Plant, AGS: Atikokan Generating Station; figures in brackets indicate the \% change of per unit biomass procurement costs from the BASE scenario.

TABLE 7: Per unit profit (\$.ODt $\left.{ }^{-1}\right)$ for each FMU from supplying biomass in different scenarios of profit maximization model.

\begin{tabular}{|c|c|c|c|c|c|c|c|c|c|c|c|c|c|}
\hline \multirow{2}{*}{ Scenario } & \multicolumn{13}{|c|}{ Per unit profit $\left(\$ \cdot \mathrm{ODt}^{-1}\right)$ for each FMU } \\
\hline & BS & CR & $\mathrm{DM}$ & DR & ER & $\mathrm{KE}$ & LS & LN & LH & SA & SR & WA & WJ \\
\hline BASE & 0.73 & 0.21 & 0.44 & 3.67 & 1.98 & -1.01 & 3.61 & -0.40 & 0.80 & 4.47 & 0.10 & 3.94 & 3.05 \\
\hline INTC & -0.74 & -0.94 & 0.28 & 2.66 & 0.56 & -2.00 & 2.17 & -2.71 & -0.58 & -0.21 & -1.85 & -0.30 & -1.32 \\
\hline IRTB1 & 7.23 & 0.21 & 6.33 & 3.67 & 2.03 & -1.01 & 3.61 & 6.10 & 7.31 & 4.47 & 6.60 & 3.94 & 3.05 \\
\hline IRTB2 & 13.73 & 0.21 & 12.22 & 3.67 & 2.10 & -1.01 & 3.61 & 12.60 & 13.81 & 4.47 & 13.10 & 3.94 & 3.05 \\
\hline IRFF1 & 0.73 & 5.63 & 0.45 & 3.67 & 1.98 & 4.15 & 3.61 & -0.40 & 0.80 & 4.48 & 0.10 & 4.19 & 3.87 \\
\hline IRFF2 & 0.73 & 11.05 & 0.45 & 3.67 & 1.98 & 9.30 & 3.61 & -0.40 & 0.80 & 4.50 & 0.10 & 4.44 & 4.68 \\
\hline IRTF1 & 7.23 & 5.63 & 6.33 & 3.67 & 2.03 & 4.15 & 3.61 & 6.10 & 7.30 & 4.48 & 6.60 & 4.19 & 3.87 \\
\hline IRTF2 & 13.73 & 11.05 & 12.23 & 3.67 & 2.09 & 9.30 & 3.61 & 12.60 & 13.80 & 4.50 & 13.10 & 4.44 & 4.68 \\
\hline
\end{tabular}

Note: BS: Black Sturgeon Forest; CR: Crossroute Forest; DM: Dog River-Matawin Forest; DR: Dryden Forest; ER: English River Forest; KE: Kenora Forest; LS: Lac Seul Forest; LN: Lake Nipigon Forest; LH: Lakehead Forest; SA: Sapawe Forest; SR: Spruce River Forest; WA: Wabigoon Forest; WJ: Whiskey Jack Forest.

will face negative gross margins, thereby halting the biomass supply hindering smooth operation of the power plants. We, therefore, tested the sensitivity of increased per unit price on part of the larger power plants to the resultant gross margin structures of biomass supplying FMUs. For this purpose, a combination of price increase scenarios at the two larger power plants (Fort Frances and Thunder Bay) is investigated. For an increase in price by $10 \%$ (IRTB1) and 20\% (IRTB2) at the Thunder Bay CHP plant, the per unit profit increases by $148 \%$ and $296 \%$ on average for all FMUs, respectively. The FMUs, which are located near the Thunder Bay CHP plant (Black-Sturgeon Forest, Dog River-Matawin Forest, English River, Lakehead Forest, Spruce River Forest, and Lake Nipigon Forest), make more per unit profit from an increase in price at the Thunder Bay CHP plant (ranging from 3.82 to $7.32 \$ \cdot \mathrm{ODt}^{-1}$ in IRTB1 and from 10.32 to $13.82 \$ \cdot \mathrm{ODt}^{-1}$ in IRTB2) because the transportation costs from these FMUs to this plant are low. Similarly, for an increase in price by $10 \%$ (IRFF1) and 20\% (IRFF2) at the Fort Frances CHP plant, the average per unit profit of FMUs increases by $54 \%$ and
$108 \%$ on average for all FMUs, respectively. Finally, if there is an increase in price of forest biomass at both the Thunder Bay and Fort Frances CHP plants by 10\% (IRTF1) and 20\% (IRTF2), the average per unit profit of FMUs increases by $202 \%$ and $404 \%$, respectively. Therefore, an increase in price of forest biomass at a power plant greatly helps to increase the profits of close by FMUs but only marginally helps to increase the profits of faraway FMUs. It is, therefore, advisable to put smaller power-plants in a wider range of area in order to make biomass collection a profitable business for FMUs. This will also help in reducing the distribution cost of powerto-small communities and increasing the rural employment through bioenergy production systems in the region.

\section{Conclusions}

This study investigates an optimal biomass supply chain for four large-scale biomass-based power plants in NWO, which has been a priority research area recently due to greater emphasis put on green energy sources in Canada 


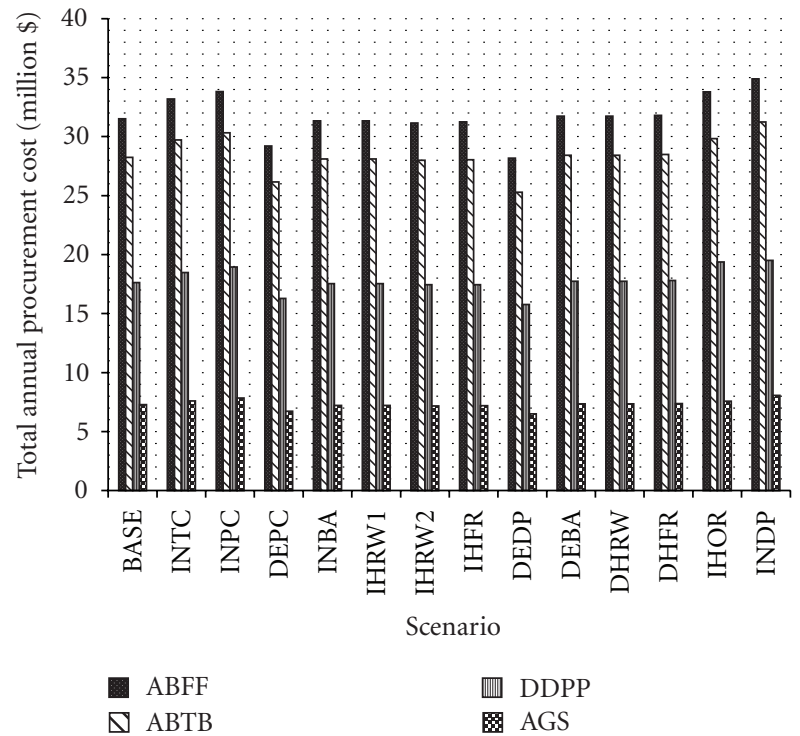

Figure 4: Total annual procurement cost of woody biomass supply to four power plants. ABFF: Abitibi-Bowater Fort Frances Power Plant, ABTB: Abitibi-Bowater Thunder Bay Power Plant, DDPP: Domtar Dryden Power Plant, AGS: Atikokan Generating Station.

and around the globe. Two optimization models have been developed and applied to analyze the impacts of biomass competition, likely to be created due to increasing demand for biomass feedstock on part of the four power plants in this region, on cost and gross margin structures for biomass based power plants. Twenty-two model scenarios (14 for cost minimization and 8 for profit maximization model) are used to study the impacts of changes relevant to economic and technological parameters of biomass procurement for each power plant and FMUs. The results show that per unit procurement costs are directly proportional to the size of the power plants in all scenarios. The highest percent increase in per unit biomass procurement costs from the base scenario is found in the increased truck charge rate by $20 \%$ scenario, followed by the scenario where only forest harvest residue biomass is used by all power plants.

The results from increased truck charge rate and FHR only scenarios point to some of the important policy implications for biomass supply chain management in NWO. The policy should focus more on controlling transportation costs by investing in transport infrastructure and logistics and rethinking of current emphasis on collecting only FHR biomass for bioenergy purpose in order to reduce the biomass procurement costs. Further, harvesting standing underutilized tree species reduces per unit procurement cost. Results from other scenarios are also important and interesting to evaluate the impacts of changing economic and technological parameters on cost structures for designing the improved decision-making strategies for power plants.

On the other hand, the results from profit maximization model are more useful to the biomass suppliers (contractors), who are interested in making maximum profits in supplying forest biomass feedstock to power plants from given
FMUs. They can maximize their profits from FMUs that are closer to the power plants. However, their profits significantly increase if the power plants offer higher prices. This is possible only if the suppliers meet the quality standards and lead time requirements of the buyers. The variations in costs and gross margin structures under various model scenarios are explained by location of depletion cells relative to power plants, availability of each type of biomass in depletion cells, biomass demands, and differential processing costs for two types of biomass. This modeling framework can be applied elsewhere to study the similar problem of biomass supply chain. The results of such modeling can help decision makers make improved decisions relating to biomass supply chains for bioenergy production.

\section{Acknowledgments}

The authors are grateful that the Ontario Ministry of Energy and Infrastructure through the Ontario Centres of Excellence, NSERC Strategic Network on VCO, AbitibiBowater Inc., and Thunder Bay Community Economic Development Commission funded this research. They are thankful to Lakehead University, Confederation College, FPInnovations FERIC Division, Lac Des Mille Lac First Nation, Buchanan Group, and Ontario Ministry of Natural Resources for further support.

\section{References}

[1] P. Rauch and M. Gronalt, "The terminal location problem in the forest fuels supply network," International Journal of Forest Engineering, vol. 21, no. 2, 2010.

[2] J. Gan and C. T. Smith, "Availability of logging residues and potential for electricity production and carbon displacement in the USA," Biomass and Bioenergy, vol. 30, no. 12, pp. 10111020, 2006.

[3] J. Wang, "Woody biomass resources, utilization, and opportunities in West Virginia, USA," in Proceedings of the 3rd Forest Engineering Conference, Mont-Treblant, October 2007.

[4] J. Kim, M. J. Realff, and J. H. Lee, "Optimal design and global sensitivity analysis of biomass supply chain networks for biofuels under uncertainty," Computers and Chemical Engineering, vol. 35, no. 9, pp. 1738-1751, 2011.

[5] T. Tahvanainen and A. Perttu, "Supply chain cost analysis of long-distance transportation of energy wood in Finland," Biomass and Bioenergy, vol. 35, no. 8, pp. 3360-3375, 2011.

[6] Centre for Energy, "Biomass energy in Canada," Canadian Centre for Energy Information," 2011, http://www.centreforenergy.com/AboutEnergy/Biomass/Overview.asp?page $=6$.

[7] Forest BioProducts Inc, "An Assessment of the Viability of Exploiting Bio-Energy Resources Accessible to the Atikokan Generating Station in Northwestern Ontario," Ontario, Canada, 2006.

[8] Ontario Power Generation Inc (OPG), "Atikokan Generation Station Biomass Repowering Project," Ontario Power Generation Inc., 2010, http://www.opg.com/power/thermal/ AtikokanFactSheet1009.pdf.

[9] J. Krarup and P. M. Pruzan, "The simple plant location problem: survey and synthesis," European Journal of Operational Research, vol. 32, no. 8, pp. 672-687, 1983.

[10] I. Macmillan, "Biomass evaluation: including a case study on woodchip utilisation at ardverikie estate, Kinlochlaggan 
[M.S. thesis], Department of Mechanical Engineering, University of Strathclyde, Glasgowuk, UK, 2001, http://www.esru .strath.ac.uk/Documents/MSc_2001/ian_macmillan.pdf.

[11] J. T. Mentzer, "Managing the Supply Chain-Managerial and Research Implications," in Supply Chain Management, J. T. Mentzer, Ed., pp. 437-461, Sage, Thousand Oaks, Calif, USA, 2001.

[12] H. Gunnarsson, M. Rönnqvist, and J. T. Lundgren, "Supply chain modelling of forest fuel," European Journal of Operational Research, vol. 158, no. 1, pp. 103-123, 2004.

[13] M. Rönnqvist, "Optimization in forestry," Mathematical Programming B, vol. 97, no. 1-2, pp. 267-284, 2003.

[14] J. Koppejan, "Fuel Storage, handling and preparation and system analysis for biomass combustion technologies," in Proceeding of the European Biomass Conference, Berlin, Germany, May 2007, http://www.conference-biomass.com/.

[15] D. Bredström, J. T. Lundgren, M. Rönnqvist, D. Carlsson, and A. Mason, "Supply chain optimization in the pulp mill industry-IP models, column generation and novel constraint branches," European Journal of Operational Research, vol. 156, no. 1, pp. 2-22, 2004.

[16] S. S. Chauhan, J. M. Frayret, and L. LeBel, "Multi-commodity supply network planning in the forest supply chain," European Journal of Operational Research, vol. 196, no. 2, pp. 688-696, 2009.

[17] L. O. Eriksson and R. Björheden, "Optimal storing, transport and processing for a forest-fuel supplier," European Journal of Operational Research, vol. 43, no. 1, pp. 26-33, 1989.

[18] S. Sokhansanj and J. Fenton, "Cost benefit of biomass supply and pre-processing," BIOCAP, Canada, 2006, http://www .biocap.ca/rif/report/Sokhansanj_S.pdf.

[19] M. Mahmoudi, T. Sowlati, and S. Sokhansanj, "Logistics of supplying biomass from a mountain pine beetle-infested forest to a power plant in British Columbia," Scandinavian Journal of Forest Research, vol. 24, no. 1, pp. 76-86, 2009.

[20] T. Sowlati, "Forest Products and Forest Biomass Transportation and Logistics," FORAC, 2009, http://www.forac.ulaval .ca/.

[21] P. Rauch, M. Gronalt, and P. Hirsch, "Co-operative forest fuel procurement strategy and its saving effects on overall transportation costs," Scandinavian Journal of Forest Research, vol. 25, no. 3, pp. 251-261, 2010.

[22] D. Freppaz, R. Minciardi, M. Robba, M. Rovatti, R. Sacile, and A. Taramasso, "Optimizing forest biomass exploitation for energy supply at a regional level," Biomass and Bioenergy, vol. 26, no. 1, pp. 15-25, 2004.

[23] F. Frombo, R. Minciardi, M. Robba, F. Rosso, and R. Sacile, "Planning woody biomass logistics for energy production: a strategic decision model," Biomass and Bioenergy, vol. 33, no. 3, pp. 372-383, 2009.

[24] C. E. Noon and M. J. Daly, "GIS-based biomass resource assessment with BRAVO," Biomass and Bioenergy, vol. 10, no. 2-3, pp. 101-109, 1996.

[25] H. Viana, W. B. Cohen, D. Lopes, and J. Aranha, "Assessment of forest biomass for use as energy. GIS-based analysis of geographical availability and locations of wood-fired power plants in Portugal," Applied Energy, vol. 87, no. 8, pp. 25512560, 2010.

[26] T. Ranta, Logging residues from regeneration fellings for biofuel production-a GIS-based availability and supply cost analysis [Ph.D. thesis], Acta Universitatis Lappeenrantaensis 128, Lappeenranta University of Technology, 2002.
[27] T. Ranta, "Logging residues from regeneration fellings for biofuel production-a GIS-based availability analysis in Finland," Biomass and Bioenergy, vol. 28, no. 2, pp. 171-182, 2005.

[28] L. Panichelli and E. Gnansounou, "GIS-based approach for defining bioenergy facilities location: a case study in Northern Spain based on marginal delivery costs and resources competition between facilities," Biomass and Bioenergy, vol. 32, no. 4, pp. 289-300, 2008.

[29] C. Perpiñá, D. Alfonso, A. Pérez-Navarro, E. Peñalvo, C. Vargas, and R. Cárdenas, "Methodology based on Geographic Information Systems for biomass logistics and transport optimisation," Renewable Energy, vol. 34, no. 3, pp. 555-565, 2009.

[30] Abitibi-Bowater Inc, "Shape Files of FRI Data (forests, roads and lake layers), Forest Depletion, and Forest Management Planning of Crossroute Forest, Dog River Matawin Forest, Black Sturgeon Forest, English River Forest, and Spruce River Forest Management Units," Personal communication with Martin Kaiser, R.P.F., Manager, Strategic Business Development, Fibre Resources Ontario, Abitibi-Bowater Inc., 2009.

[31] Greenmantle Forest Inc, "Shape files of FRI Data, (forests, roads and lake layers), forest depletion, and Forest Management Planning of Lakehead Forest Management Unit," Personal communication with Dave MacIsaac, Area Forester, Greenmantle Forest Inc., Thunder Bay, Ontario, 2009.

[32] GreenForest Management Inc, "PDF files of block area and timber volumes and shape files of FRI Data, (forests, roads and lake layers), forest depletion, and Forest Management Planning of Sapawe Forest Management Unit," Personal communication with Richard Shwedack, R.P.F., GreenForest Management Inc., Thunder Bay, Ontario, 2009.

[33] Land Information Ontario (LIO), "Geographic Information System (GIS) data for the Forest Management Units (FMUs) of Northwestern Ontario," Personal Communication with Land Information Ontario (LIO), 2010.

[34] S. J. Nicholls, R. E. Pulkki, and P. A. Ackerman, "Provincial road condition and round wood timber transport in South Africa," Southern African Forestry Journal, vol. 207, pp. 55-61, 2006.

[35] Environmental Systems Research Institute (ESRI), "ArcGIS 9.3 Desktop Help," Environmental Systems Research Institute (ESRI), Inc., 2010, http://webhelp.esri.com/arcgisdesktop/9.3/ index.cfm?TopicName=welcome.

[36] M. B. Alam, R. Pulkki, and C. Shahi, "Road network optimization model for supplying woody biomass feedstock for energy production in northwestern Ontario," The Open Forest Science Journal, vol. 5, pp. 1-14, 2012. 

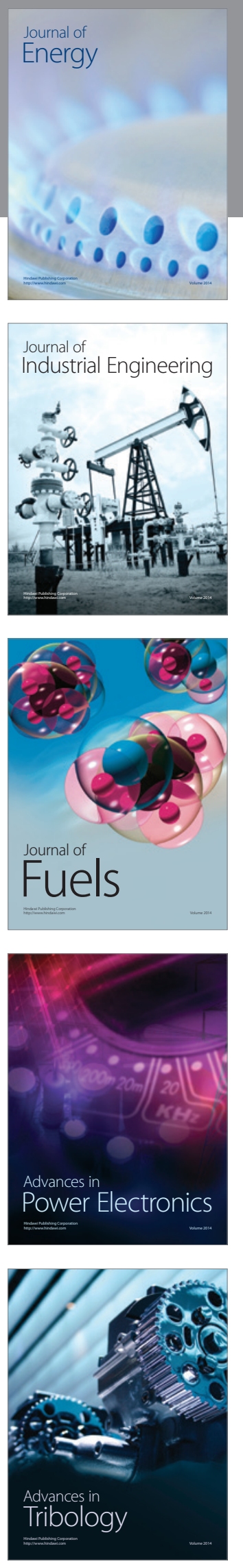
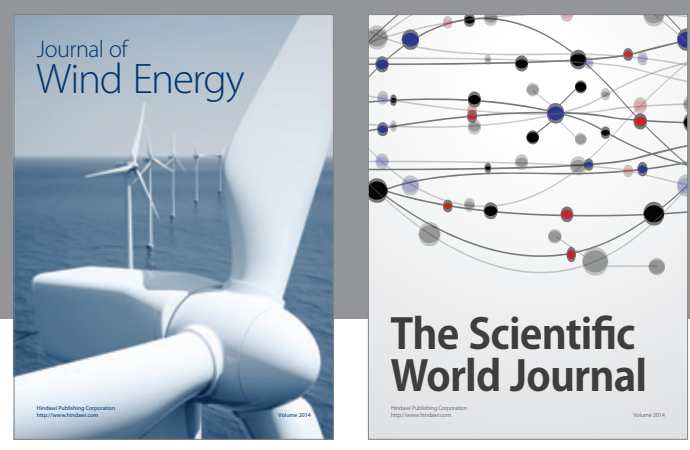

The Scientific World Journal

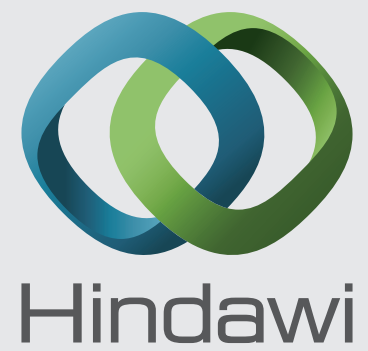

Submit your manuscripts at http://www.hindawi.com
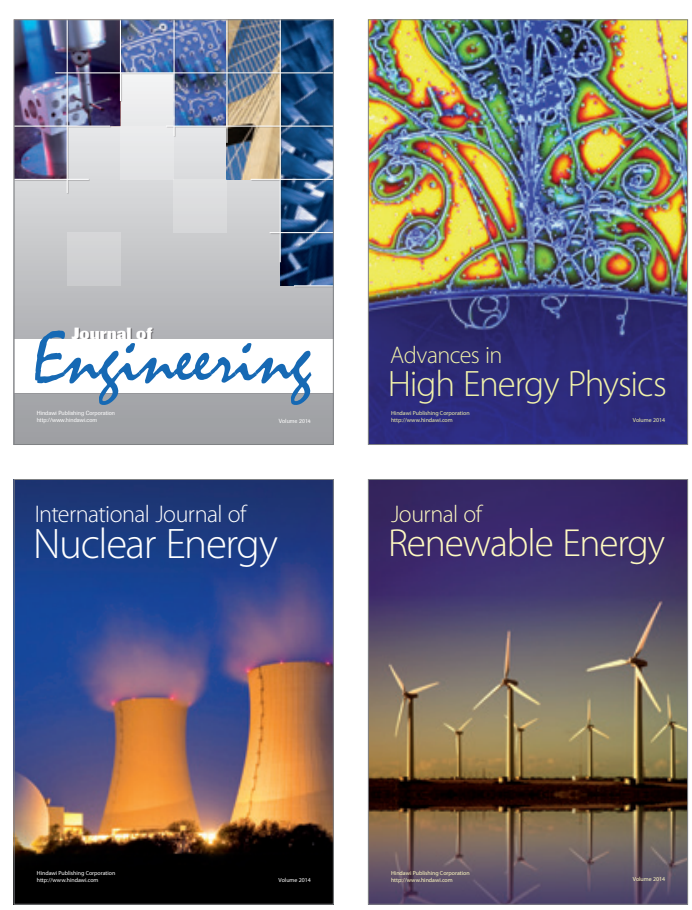

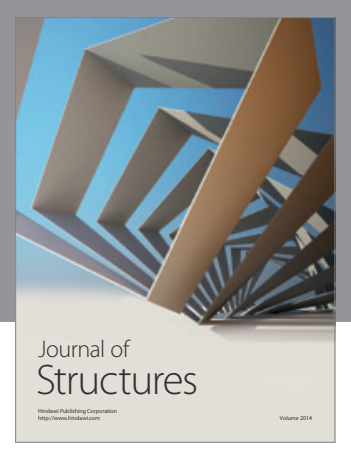

Rotating
Mechinery
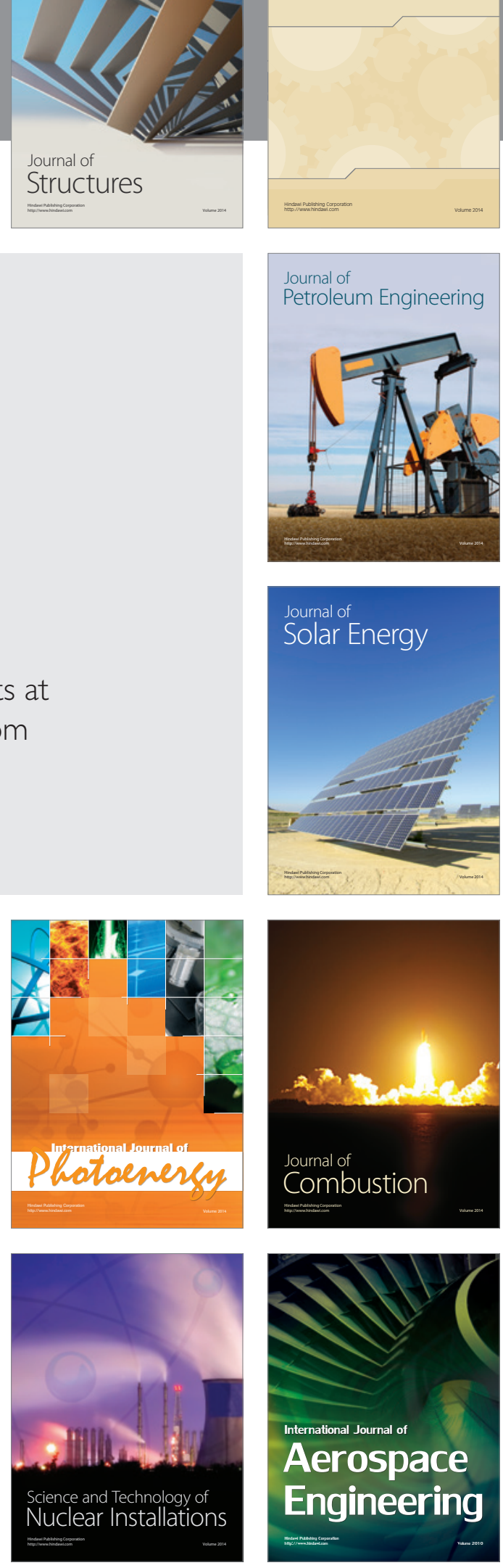